\title{
EKSPERIMENTASI MODEL PEMBELAJARAN KOOPERATIF TIPE STUDENT TEAMS ACHIEVEMENT DIVISIONS MODIFIKASI PENEMUAN TERBIMBING TERHADAP PRESTASI BELAJAR MATEMATIKA DITINJAU DARI KEMAMPUAN VERBAL
}

\author{
Herlina (jc.herlina@gmail.com) \\ Universitas Negeri Sebelas Maret, Surakarta
}

\begin{abstract}
The purpose of this study was to compare the learning achievement using cooperative learning model Student Teams Achievement Divisions with cooperative learning model Student Teams Achievement Divisions modification of guided discovery in terms of verbal abality. Based on the results of the study concluded that (1) based on a model of learning, the mathematics achievement of students who use cooperative learning model Student Teams Achievement Divisions as good with mathematics achievement of students who use cooperative learning model Student Teams Achievement Divisions modifications guided discovery, both on students who have the high verbal skills, medium and low, (2) base on terms of verbal skills, mathematics achievement of students who have high verbal ability is better than mathematics achievement of students who have medium and low verbal ability, and mathematics achievement of students have medium verbal skills better than mathematics achievement of students have the ability low verbal skills.
\end{abstract}

Keywords: mathematics achievement, student teams achievement divisions modification guided discovery, student teams achievement divisions, verbal ability

\begin{abstract}
ABSTRAK
Tujuan penelitian ini adalah untuk mengetahui perbandingan prestasi belajar yang menggunakan model pembelajaran kooperatif tipe Student Teams Achievement Divisions dengan model pembelajaran kooperatif tipe Student Teams Achievement Divisions modifikasi penemuan terbimbing ditinjau dari kemampuan verbal. Berdasarkan hasil penelitian disimpulkan bahwa (1) berdasarkan model pembelajaran, prestasi belajar matematika peserta didik yang menggunakan model pembelajaran kooperatif tipe Student Teams Achievement Divisions sama baiknya dengan prestasi belajar matematika peserta didik yang dikenai model pembelajaran kooperatif tipe Student Teams Achievement Divisions modifikasi penemuan terbimbing, baik pada peserta didik yang memiliki kemampuan verbal tinggi, sedang dan rendah, (2) ditinjau dari kemampuan verbal, peserta didik yang memiliki kemampuan verbal tinggi lebih baik daripada peserta didik yang memiliki kemampuan verbal sedang dan rendah, dan peserta didik yang memiliki kemampuan verbal sedang lebih baik daripada peserta didik yang memiliki kemampuan verbal rendah.
\end{abstract}

Kata kunci: kemampuan verbal, prestasi belajar matematika, student teams achievement divisions modifikasi penemuan terbimbing, student teams achievement divisions 
Matematika merupakan mata pelajaran yang diajarkan di sekolah mulai dari taman kanakkanak sampai perguruan tinggi karena matematika sangat penting dalam perkembangan ilmu pengetahuan dan teknologi. Untuk menguasai dan menciptakan teknologi dimasa depan diperlukan penguasaan matematika yang kuat sejak dini. Konsep-konsep dalam bidang matematika merupakan rangkaian bersifat sebab akibat, dimana suatu konsep disusun berdasarkan konsep-konsep sebelumnya dan akan menjadi dasar konsep selanjutnya. Dengan demikian pemahaman konsep yang salah akan berakibat pada kesalahan terhadap pemahaman konsep selanjutnya. Sementara matematika masih dipandang mata pelajaran yang menakutkan, membosankan dan memerlukan konsentrasi yang cukup tinggi untuk dapat memahaminya. Sugianto (2010: 1), daya tarik suatu mata pelajaran ditentukan oleh dua hal, pertama oleh mata pelajaran itu sendiri, dan kedua oleh cara mengajar guru. Oleh karena itu tugas seorang guru yang profesional akan menjadikan pelajaran yang sebelumnya tidak menarik menjadi menarik, yang dirasakan sulit menjadi mudah, dan yang tadinya tidak berarti menjadi berarti.

Berdasarkan Hasil Ujian Nasional matematika peserta didik SMA 2009/2010 baik tingkat Nasional, tingkat Provinsi dan tingkat Kabupaten atau Kota tidak menunjukkan hasil yang sepadan. Di tingkat Provinsi Jawa Tengah Kota Surakarta, Perbandingan nilai Ujian Nasional matematika peserta didik SMA 2009/2010 dapat dilihat pada tabel 1berikut ini

Tabel 1. Prestasi Belajar Matematika Peserta Didik SMA pada Ujian Nasional 2009/2010

\begin{tabular}{lccc}
\hline \multirow{2}{*}{ Tingkat } & \multicolumn{3}{c}{ Kategori } \\
\cline { 2 - 4 } & Nasional & Provinsi Jawa Tengah & Kota surakarta \\
\hline Rerata & 8,09 & 7,26 & 5,62 \\
Nilai Tertinggi & 10,00 & 10,00 & 10,00 \\
Nilai Terendah & 0,25 & 1,00 & 1,00 \\
Standar deviasi & 1,40 & 1,43 & 1,38 \\
\hline
\end{tabular}

(sumber : Badan standar Nasional Pendidikan)

Berdasarkan laporan hasil Ujian Nasional 2009/2010, rerata prestasi belajar matematika peserta didik SMA di Kota Surakarta lebih rendah dibandingkan rerata prestasi belajar matematika peserta didik SMA di tingkat Propinsi Jawa Tengah maupun Nasional. Dari 2.455 peserta Ujian Nasional SMA di Kota Surakarta pada 2009/2010, terdapat 383 peserta didik 15,601\% yang memperoleh nilai matematika di bawah nilai rata-rata. Kebanyakan peserta didik mengalami ketidaklulusan pada mata pelajaran matematika. Data tersebut menunjukkan bahwa penguasaan konsep matematika peserta didik SMA di Kota Surakarta masih rendah. Hal tersebut juga menunjukkan pelaksanaan peningkatan kualitas pendidikan di bidang pembelajaran matematika belum terlaksana dengan baik, terutama di Kota Surakarta.

Berdasarkan informasi dari beberapa guru matematika SMA dan pengalaman beberapa peserta didik SMA di Kota Surakarta, mengemukakan bahwa salah satu kesulitan peserta didik adalah pada materi sistem persamaan linier dua variabel. Informasi tersebut dipertegas oleh hasil analisis daya serap peserta didik SMA di Kota Surakarta pada Ujian Nasional 2009/2010. Hasil analisis daya serap terhadap kemampuan yang berkaitan dengan materi sistem persamaan linier dua variabel yang diujikan pada Ujian Nasional 2009/2010 menunjukkan penguasaan konsep sistem 
persamaan linier dua variabel oleh peserta didik SMA di Kota Surakarta kurang optimal dibanding tingkat Provinsi dan Nasional (Table 2).

Tabel 2. Penguasaan Konsep Peserta Didik SMA di Kota Surakarta Berkaitan dengan Materi Sistem Persamaan Linier Dua Variabel pada Ujian Nasional 2009/2010.

\begin{tabular}{ccccc}
\hline \multirow{2}{*}{$\begin{array}{c}\text { No } \\
\text { Soal }\end{array}$} & Kemampuan yang Diuji & \multicolumn{3}{c}{$\begin{array}{c}\text { Presentase Penguasaan Konsep } \\
(\text { dalam \%) }\end{array}$} \\
\cline { 3 - 5 } & $\begin{array}{l}\text { Tingkat } \\
\text { Rayon }\end{array}$ & $\begin{array}{l}\text { Tingkat } \\
\text { Propinsi }\end{array}$ & $\begin{array}{c}\text { Tingkat } \\
\text { Nasional }\end{array}$ \\
\hline 12 & $\begin{array}{l}\text { Menyelesaikan masalah yang berkaitan } \\
\text { dengan sistem persamaan linier dua } \\
\text { variabel }\end{array}$ & 68,83 & 78,16 & 86,42 \\
\hline
\end{tabular}

Sebagian besar peserta didik SMA di Kota Surakarta mengalami kesulitan dalam menyelesaikan soal-soal yang berkaitan dengan konsep sistem persamaan linier dua variabel. Kesulitan-kesulitan yang dialami oleh peserta didik SMA di Kota Surakarta dalam menyelesaikan soal-soal sistem persamaan linier dua variabel dimungkinkan karena peserta didik belum benarbenar menguasai konsep-konsep sistem persamaan linier dua variabel dan hanya mengorganisir sendiri tanpa mengkomunikasikan secara kooperatif. Selain itu, yang menyebabkan daya serap hasil Ujian Nasional 2009/2010 kurang optimal adalah dimungkinkan sebagian besar guru matematika belum menerapkan pembelajaran aktif.

Berdasarkan uraian diatas penelitian ini mencoba mengesperimenkan model pembelajaran kooperatif tipe Student Teams Achievement Divisions (STAD), khususnya pembelajaran Student Teams Achievement Divisions (STAD) modifikasi penemuan terbimbing dalam rangka mengembangkan teori konstruktivisme ditinjau dari kemampuan verbal peserta didik terhadap prestasi belajar untuk mencapai prestasi belajar yang lebih maksimal.

Dalam Agus Suprijono (2010: 6), prestasi belajar seorang peserta didik mencakup kemampuan kognitif, afektif, dan psikomotor. Azwar Saiffudin (2003: 9), prestasi belajar adalah performance maksimal subyek dalam menguasai bahan-bahan atau materi yang diajarkan. Prestasi belajar dapat didefinisikan sebagai tingkat pemahaman dan penguasaan pengetahuan atau keterampilan terhadap suatu konsep dalam mata pelajaran tertentu. Sehingga dapat disimpulkan bahwa prestasi belajar matematika adalah hasil belajar yang dicapai peserta didik dalam melakukan suatu kegiatan pembelajaran matematika dengan disertai adanya perubahan tingkah laku sebagai hasil interaksi antara stimulus dan respon yang berupa kecakapan, sikap, kebiasaan, kepandaian atau suatu pengertian yang dinyatakan dalam bentuk simbol, angka, huruf maupun kalimat.

Model Pembelajaran Kooperatif tipe Student Teams Achievement Divisions (STAD) dikembangkan oleh Robert Slavin dan teman-temannya di Universitas John Hopkin. Model ini juga sangat mudah diadaptasi dan digunakan dalam matematika, sains, ilmu pengetahuan sosial, bahasa Inggris, teknik dan lain-lain pada tingkat sekolah menengah sampai perguruan tinggi. Dalam penelitian Balfakih (2003: 605), menjelaskan bahwa

"Investigates the effectives of Student-Team Achievement division for teaching chemistry in randomly selected high school classes in the United Arab Emirates (UAE). Also examines the differences among groups with regard to gender, geographic area, and ability. Finding indicate that STAD is a more effective teaching method than 
traditional teaching methods in teaching 10th grade chemistry classes in the United Arab Emirate (UAE)".

Berdasarkan uraian tersebut menjelaskan bahwa model pembelajaran (STAD) lebih efektif daripada model pembelajaran tradisional, jika dalam kelompok terdapat peserta didik yang berbeda jenis kelamin, asal daerah dan kemampuan peserta didik. Dalam pembelajaran kooperatif tipe STAD peserta didik dibagi menjadi kelompok-kelompok kecil yang beranggotaan 4-5 orang yang beragam kemampuan, jenis kelamin dan suku. Guru memberikan hantaran kepada peserta didik di setiap kelompok untuk memastikan bahwa semua anggota kelompok dapat menguasai materi yang dibahas. Setelah proses diskusi kelompok peserta didik diminta untuk menuliskan jawabannya di depan kelas untuk evaluasi bersama.Pada akhirnya, peserta didik diberi kuis dan dilarang untuk saling membantu satu sama lain. Sehingga setiap peserta didik harus menguasai materi tersebut (bertanggung jawab secara individu).

Menurut Michael (2010: 83-89) the main purpose of Student Teams Achievement Divisions (STAD) is to drastically improve and accelerate learner performance. Uraian tersebut menjelaskan bahwa tujuan utama dari Student Teams Achievement Divisions adalah untuk meningkatkan dan mempercepat kinerja belajar. Secara garis besar model kooperatif tipe Student Teams Achievement Divisions terdiri dari enam langkah dalam Trianto (2010: 71), yaitu:

1. menyampaikan tujuan dan memotivasi peserta didik. Guru menyampaikan semua tujuan pembelajaran yang ingin dicapai pada pelajaran tersebut dan memotivasi peserta didik belajar.

2. presentasi dari guru. Guru memberikan informasi materi pelajaran kepada peserta didik dengan dibantu media, demonstrasi, pertanyaan atau masalah nyata yang terjadi dalam kehidupan sehari-hari. Selain itu, guru menjelaskan keterampilan dan kemampuan yang harus dikuasi oleh peserta didik melalui tugas yang diberikan.

3. pembentukan kelompok. Peserta didik dibagi ke dalam beberapa kelompok dimana setiap kelompok terdiri dari 4-5 peserta didik yang memprioritaskan heterogenitas kelas dalam prestasi akademik, gender/jenis kelamin dan suku.

4. membimbing kelompok bekerja dan belajar dalam tim. Peserta didik belajar dalam kelompok yang telah dibentuk. Guru menyiapkan lembaran kerja sebagai pedoman bagi kerja kelompok, sehingga semua anggota dapat menguasai dan masing-masing memberi kontribusi. Selama tim kerja, guru melakukan pengamatan, memberikan bimbingan, dorongan dan bantuan bila diperlukan. Kerja tim ini merupakan ciri terpenting dari (STAD).

5. evaluasi. Guru mengevaluasi hasil belajar melalui pemberian kuis tentang materi yang dipelajari dan melakukan penilaian terhadap presentasi hasil kerja masing-masing kelompok. Peserta didik diminta untuk kembali ke tempat duduk masing-masing kemudian memberikan kuis dan peserta didik bekerja secara mandiri. Hal ini dilakukan untuk menjamin agar peserta didik secara individu bertanggung jawab kepada diri sendiri dalam memahami bahan ajar tersebut.

6. pemberian penghargaan. Setelah pelaksanaan kuis, guru memeriksa hasil kerja peserta didik dan diberikan angka dengan rentang 0-100.

Dari tinjauan pembelajaran kooperatif tipe (STAD) menunjukan bahwa pembelajaran kooperatif cukup sederhana. Hal ini karena kegiatan pembelajaran yang dilakukan masih dekat kaitannya dengan pembelajaran konvensional. Hal ini dapat dilihat dari langkah kedua pembelajaran kooperatif tipe (STAD) yaitu adanya penyajian informasi atau materi pelajaran. Perbedaan model ini dengan konvensional terletak pada pemberian penghargaan pada kelompok. 
Model pembelajaran kooperatif tipe STAD dengan modifikasi penemuan terbimbing adalah suatu model pembelajaran pengembangan dari model pembelajaran kooperatif tipe Student Teams Achievement Divisions. Perbedaannya dapat dilihat pada Tabel 3.

Tabel 3. Perbedaan Langkah-langkah Model Pembelajaran Kooperatif tipe STAD Modifikasi Penemuan Terbimbing dengan Model Pembelajaran tipe Kooperatif STAD

\begin{tabular}{|c|c|c|}
\hline Langkah-langkah & $\begin{array}{c}\text { Model Pembelajaran Kooperatif tipe } \\
\text { STAD Modifikasi Penemuan } \\
\text { Terbimbing }\end{array}$ & $\begin{array}{l}\text { Model Pembelajaran } \\
\text { Kooperatif Tipe STAD }\end{array}$ \\
\hline $\begin{array}{l}\text { Langkah } 1 \\
\text { Menyampaikan } \\
\text { tujuan dan } \\
\text { memotivasi peserta } \\
\text { didik }\end{array}$ & $\begin{array}{l}\text { Guru menyampaikan semua tujuan } \\
\text { pembelajaran yang ingin dicapai pada } \\
\text { pelajaran tersebut dan memotivasi } \\
\text { peserta didik }\end{array}$ & $\begin{array}{l}\text { Guru menyampaikan semua } \\
\text { tujuan pembelajaran yang } \\
\text { ingin dicapai pada pelajaran } \\
\text { tersebut dan memotivasi } \\
\text { peserta didik belajar. }\end{array}$ \\
\hline $\begin{array}{l}\text { Langkah } 2 \\
\quad \text { Menyajikan informasi }\end{array}$ & $\begin{array}{l}\text { Guru menyajikan informasi kepada } \\
\text { peserta didik dengan cara } \\
\text { membimbing peserta didik dalam } \\
\text { memecahkan permasalahan yang } \\
\text { telah disajikan dalam bentuk lembar } \\
\text { bimbingan belajar penemuan } \\
\text { sehingga peserta didik dapat } \\
\text { menemukan konsep matematika. }\end{array}$ & $\begin{array}{l}\text { Guru menyajikan informasi } \\
\text { kepada peserta didik baik } \\
\text { dengan peragaan } \\
\text { (demonstrasi) atau teks. }\end{array}$ \\
\hline $\begin{array}{l}\text { Langkah } 3 \\
\text { Mengorganisasikan } \\
\text { peserta didik ke } \\
\text { dalam kelompok- } \\
\text { kelompok belajar }\end{array}$ & $\begin{array}{l}\text { Guru menjelaskan dan membimbing } \\
\text { peserta didik bagaimana caranya } \\
\text { membentuk kelompok belajar dan } \\
\text { membantu setiap kelompok agar } \\
\text { melakukan perubahan yang efisien. }\end{array}$ & $\begin{array}{l}\text { Guru menjelaskan peserta } \\
\text { didik bagaimana caranya } \\
\text { membentuk kelompok belajar } \\
\text { dan membantu setiap } \\
\text { kelompok agar melakukan } \\
\text { perubahan yang efisien. }\end{array}$ \\
\hline $\begin{array}{l}\text { Langkah } 4 \\
\text { Membantu kerja } \\
\text { kelompok dalam } \\
\text { belajar }\end{array}$ & $\begin{array}{l}\text { Guru membimbing kelompok- } \\
\text { kelompok belajar pada saat mereka } \\
\text { mengerjakan tugas. }\end{array}$ & $\begin{array}{l}\text { Guru membimbing kelompok- } \\
\text { kelompok belajar pada saat } \\
\text { mereka mengerjakan tugas. }\end{array}$ \\
\hline $\begin{array}{l}\text { Langkah } 5 \\
\text { Evaluasi }\end{array}$ & $\begin{array}{l}\text { Guru mengevaluasi materi pelajaran } \\
\text { atau kelompok dan menyajikan hasil- } \\
\text { hasil pekerjaan mereka. }\end{array}$ & $\begin{array}{l}\text { Guru mengevaluasi materi } \\
\text { pelajaran atau kelompok } \\
\text { menyajikan hasi-hasil } \\
\text { pekerjaan mereka. }\end{array}$ \\
\hline $\begin{array}{l}\text { Langkah } 6 \\
\text { Memberikan } \\
\text { penghargaan }\end{array}$ & $\begin{array}{l}\text { Guru memberikan cara-cara untuk } \\
\text { menghargai baik upaya maupun hasil } \\
\text { belajar individu dan kelompok. }\end{array}$ & $\begin{array}{l}\text { Guru memberikan cara-cara } \\
\text { untuk menghargai baik upaya } \\
\text { maupun hasil belajar individu } \\
\text { dan kelompok. }\end{array}$ \\
\hline
\end{tabular}

Dengan demikian, perbedaan antara model pembelajaran kooperatif tipe STAD modifikasi penemuan terbimbing dengan model pembelajaran kooperatif tipe STAD adalah terletak pada langkah kedua yaitu pada saat menyampaikan materi. Pada model pembelajaran kooperatif tipe 
STAD modifikasi penemuan terbimbing penyampaian informasi materi dengan metode penemuan terbimbing dengan menggunakan lembar bimbingan belajar penemuan sedangkan pada model pembelajaran kooperatif tipe STAD dengan metode ceramah.

Dalam hal ini, ketika peserta didik hanya mendengar atau menerima informasi tanpa peserta didik melakukan sendiri maka peserta didik akan mudah melupakannya, sehingga pengetahuan peserta didik menjadi tidak bermakna. Dalam Markaban (2006: 3), mengetahui adalah suatu proses, bukan suatu produk. Proses tersebut dimulai dari pengalaman, sehingga peserta didik harus diberi kesempatan seluas luasnya untuk mengkonstruksi sendiri pengetahuan yang harus dimiliki.

Penemuan terbimbing merupakan suatu cara untuk menyampaikan ide atau gagasan melalui proses menemukan dengan suatu bimbingan. Dimana guru mengarahkan atau memberi petunjuk kepada peserta didik mengenai materi yang akan dipelajari. Dengan bimbingan ini peserta didik diajak untuk melakukan kegiatan sedemikian rupa yang akhirnya diharapkan peserta didik dapat menemukan sesuatu yang dipelajarinya. Peserta didik diharapkan dapat menemukan pola-pola atau struktur-struktur melalui sederetan pengalaman belajar. Bentuk bimbingan yang diberikan guru bisa berupa petunjuk, arahan, pertanyaan, dialog kesimpulan, atau generalisasi sesuai dengan yang diinginkan guru. Dalam Mumba (2007: 2) menyatakan bahwa "Teaching and learning science by inquiry involves the means by which students gain knowledge, it includes the development of inquiry skills, such as the abilities to: identify and define a problem, formulate a hypothesis, design an experiment, collect and analyze data, and interpret data and draw meaningful conclusions".

Berdasarkan uraian tersebut menjelaskan bahwa mengajar dan belajar ilmu pengetahuan dengan penyelidikan melibatkan cara-cara mendapatkan dari pengetahuan yang mencakup pengembangan keterampilan penyelidikan peserta didik seperti kemampuan untuk mengidentifikasi dan mendefinisikan masalah, merumuskan hipotesis, desain eksperimen, mengumpulkan, menganalisis data, menafsirkan data dan menggambarkan makna kesimpulan. Dengan demikian, peserta didik akan lebih mudah memahami konsep-konsep yang dipelajari.

Kemampuan verbal merupakan faktor dalam yang mampu mempengaruhi proses pembelajaran. Tingkat kemampuan verbal yang dimiliki masing-masing peserta didik berbeda-beda. Hal tersebut dipengaruhi oleh faktor genetik dan faktor lingkungan. Menurut Hariwijaya (2005: 8), kemampuan verbal meliputi kemampuan berkomunikasi secara urut, runtut, tertata, sistematis, tepat dan penempatan posisi diri. Dalam proses pembelajaran, lingkungan dirancang sebagai media yang mampu meningkatkan kemampuan peserta didik. Kemampuan verbal merupakan kecerdasan yang berhubungan dengan kemampuan seseorang dalam berkomunikasi dengan sesama manusia. Individu dengan kemampuan verbal tinggi maka kemampuan berkomunikasi dengan sesama pasti baik.

Untuk memahami konsep-konsep dan prinsip-prinsip matematika diperlukan kemampuan verbal yang dapat digunakan untuk menerjemahkan konsep-konsep ke dalam bahasa symbol. Selanjutnya menerjemahkan kembali simbol-simbol itu ke konsep-konsep dunia nyata. Penggunaan simbol dalam matematika adalah mempermudah penulisan dengan singkat, tepat dan dapat dimengerti. Simbol dalam matematika digunakan sebagai komunikasi, dan komunikasi ini akan memberikan pengertian hubungan dengan konsep-konsep. Kemampuan verbal dalam matematika meliputi kemampuan memahami dan mengingat arti kata-kata, istilah-istilah matematika yang terdapat dalam soal. Kekeliruan dalam memahami kata-kata dapat mengakibatkan kesalahan fatal. Jujun (2007: 190), matematika adalah bahasa yang dilambangkan serangkaian makna dari suatu pernyataan yang dituliskan dengan simbol-simbol. Simbol-simbol tersebut bersifat artifisial dan baru mempunyai arti setelah sebuah makna diberikan serta merupakan sebuah perjanjian yang berlaku 
khusus pada matematika. Dalam kasus soal verbal, menerjemahkan situasi masalah kedalam kalimat matematika kemampuan verbal peserta didik diperlukan untuk dapat menerjemahkan situasi yang dihadapi. Jadi kemampuan verbal peserta didik adalah kemampuan berbahasa dalam menerjemahkan pemikiran konseptual ke dalam bahasa lisan atau tulisan secara urut, runtut, tertata dan sistematis.

\section{METODE}

Penelitian ini merupakan penelitian eksperimental semu dengan desain faktorial $2 \times 3$. Menurut Budiyono (2003: 82-83), tujuan dari penelitian eksperimental semu adalah untuk memperoleh informasi yang merupakan perkiraan bagi informasi yang dapat diperoleh dengan eksperimen yang sebenarnya dalam keadaan yang tidak memungkinkan untuk mengontrol dan/atau memanipulasikan semua variabel yang relevan.

Menurut Sugiyono (2007:117), populasi adalah wilayah generalisasi yang terdiri atas obyek/subyek yang mempunyai kualitas dan karakteristik tertentu yang ditetapkan oleh peneliti untuk diteliti dan kemudian ditarik kesimpulan. Populasi penelitian ini adalah seluruh peserta didik SMA di Kota Surakarta.

Sampel adalah bagian dari populasi yang mewakili karakteristik yang ada pada populasi. Menurut Budiyono (2009: 121), sebagian populasi yang diamati disebut sampel atau contoh. Dengan demikian, dalam penelitian ini telah diambil tiga SMA yang terdapat pada populasi untuk dijadikan sampel. Pengambilan sampel dilakukan dengan teknik stratified cluster random sampling. Sampel dalam penelitian ini sebanyak 126 peserta didik, dengan rincian 61 peserta didik pada kelas eksperimen satu dan 65 peserta didik pada kelas eksperimen dua.

Menurut Budiyono (2003: 47), metode pengumpulan data diartikan sebagai cara-cara yang dilakukan peneliti untuk mengumpulkan data. Dalam penelitian ini, metode pengumpulan data yang digunakan meliputi metode-metode tes. Yang meliputi tes kemampuan verbal dan tes matematika persamaan linier dengan menggunakan instrumen.

Menurut Budiyono (2003: 47), instrumen pengumpulan data adalah alat bantu yang dipilih dan digunakan oleh peneliti (atau orang lain yang ditugasi) dalam kegiatan pengumpulan data agar kegiatan pengumpulan data menjadi sistematis dan mudah. Instrumen yang digunakan untuk mengumpulkan data adalah tes kemampuan verbal dan tes prestasi belajar matematika.

Budiyono (2003:60-71) menunjukkan uji coba instrumen tes meliputi validitas isi, tingkat kesukaran, daya pembeda, dan reliabilitas. Uji prasyarat meliputi uji normalitas populasi menggunakan metode Lilliefors dan uji homogenitas variansi populasi menggunakan metode Bartlett dengan $\alpha=0,05$. Simpulan yang diperoleh menunjukkan sampel berasal dari populasi yang berdistribusi normal dan mempunyai variansi yang homogeny. Uji keseimbangan terhadap data kemampuan awal matematika menggunakan uji-t. Simpulan diperoleh menunjukkan kedua kelas eksperimen mempunyai kemampuan awal matematika yang seimbang. Pengujian hipotesis menggunakan analisis variansi dua jalan dengan sel tak sama.

\section{HASIL DAN PEMBAHASAN}

Analisis variansi dua jalan pada sel yang tak sama dilakukan setelah uji prasyarat yakni uji normalitas dan uji homogenitas terpenuhi. Dimana populasi-populasi berdistribusi normal dan perbandingan populasi-populasi memiliki variansi yang homogen. Tujuan dari analisis variansi ini adalah untuk mengetahui apakah terdapat perbedaan prestasi belajar matematika peserta didik pada kategori model pembelajaran dan pada kategori kemampuan verbal serta mengetahui apakah 
terdapat interaksi terhadap prestasi belajar matematika peserta didik. Analisis ini menggunakan taraf signifikan 0,05 . Perhitungan analisis variansi dua jalan dengan sel tak sama dapat dilihat pada Tabel 4.

Tabel 4. Hasil Analisis Variansi Dua Jalan.

\begin{tabular}{lcccccc}
\hline \multicolumn{1}{c}{ Sumber } & JK & $\mathrm{dk}$ & $\mathrm{RK}$ & $\mathrm{F}_{\text {hit }}$ & $\mathrm{F}_{\text {tab }}$ & $\begin{array}{c}\text { Kep. Uji } \\
\text { Hipotesis }\end{array}$ \\
\hline Metode (A) & 437,099315 & 1 & 437,099315 & 1,45788343 & 3,92012 & Diterima \\
$\begin{array}{l}\text { Kemampuan } \\
\text { Verbal (B) }\end{array}$ & 21994,5788 & 2 & 10997,2894 & 36,6799156 & 3,077178 & Ditolak \\
$\begin{array}{l}\text { Interaksi } \\
\text { (AB) }\end{array}$ & 1394,36833 & 2 & 299,817739 & 2,32535996 & 3,07178 & Diterima \\
Galat & 35978,1287 & 120 & - & - & - & - \\
\hline Total & 59804,1751 & 125 & - & - & - & - \\
\hline
\end{tabular}
berikut:

Berdasarkan hasil analisis variansi dua jalan dengan sel tak sama, dijelaskan sebagai

1. Nilai $F_{A}=1,45788343$ kurang dari nilai $F_{0,05 ; 1 ; 120}=3,92012$. HoA tidak terletak pada daerah kritis, sehingga $\mathrm{H}_{0 \mathrm{~A}}$ tidak ditolak. Hal ini menunjukkan bahwa prestasi belajar matematika peserta didik pada masing-masing kategori model pembelajaran memiliki prestasi belajar matematika peserta didik yang sama baik. Dengan kata lain, tidak terdapat perbedaan prestasi belajar matematika pada peserta didik yang dikenai model pembelajaran kooperatif tipe STAD modifikasi penemuan terbimbing dan model pembelajaran kooperatif tipe STAD.

2. Nilai $F_{B}=36,6799156$ lebih dari nilai $F 0,05 ; 2 ; 120=3,07178$. $H_{0 B}$ terletak pada daerah kritis sehingga $\mathrm{H}_{0 \mathrm{~B}}$ ditolak. Hal ini menunjukkan bahwa terdapat perbedaan prestasi belajar matematika peserta didik pada setiap kategori kemampuan verbal.

3. Nilai $F_{A B}=2,32535996$ lebih dari nilai $F 0,05 ; 2 ; 120=3,07178$. $\mathrm{H}_{\mathrm{OAB}}$ tidak terletak pada daerah kritis sehingga $\mathrm{H}_{O A B}$ tidak ditolak. Hal ini menunjukkan bahwa tidak terdapat interaksi antara model pembelajaran dan kemampuan verbal terhadap prestasi belajar matematika peserta didik. Sehingga perbandingan antar sel pada baris dan kolom yang sama, mengikuti perlakuan yang ada pada induknya yaitu efek utama $A$ (Model Pembalajaran) dan $B$ (kemampuan verbal).

Uji komparasi ganda ini dilakukan jika $\mathrm{H}_{0 B}$ ditolak dan $\mathrm{H}_{0 \mathrm{AB}}$ ditolak. Keputusan uji pada $\mathrm{H}_{0 \mathrm{~A}}$ adalah tidak ditolak sehingga tidak ada uji komparasi antar baris. Untuk $\mathrm{H}_{0 \mathrm{~B}}$ ditolak maka perlu uji komparasi antar kolom dan untuk $\mathrm{H}_{\mathrm{OAB}}$ tidak ditolak sehingga tidak ada uji komparasi antar sel. Tujuan dari uji komparasi ganda ini adalah untuk mengetahui kategori manakah yang secara signifikan memberikan rerata yang berbeda dengan kategori lainnya. Berdasarkan keputusan uji pada analisis variansi dua jalan dengan sel tak sama maka akan dipaparkan sebagai berikut.

1. $\mathrm{H}_{0 \mathrm{~A}}$ tidak ditolak. Berdasarkan Tabel $4, \mathrm{H}_{0 \mathrm{~A}}$ tidak ditolak menunjukkan bahwa model pembelajaran kooperatif tipe STAD modifikasi penemuan terbimbing dan model pembelajaran kooperatif tipe STAD memberikan efek yang sama. Ini berarti prestasi belajar matematika peserta didik adalah sama baiknya. Dengan demikian, disimpulkan bahwa prestasi belajar matematika peserta didik yang dikenai model pembelajaran kooperatif tipe STAD modifikasi penemuan terbimbing sama baiknya dengan prestasi belajar matematika peserta didik yang dikenai model pembelajaran kooperatif tipe STAD. 
2. $\mathrm{H}_{0 \mathrm{~B}}$ ditolak. Berdasarkan Tabel $4, \mathrm{H}_{0 \mathrm{~B}}$ ditolak menunjukkan bahwa terdapat perbedaan prestasi belajar matematika peserta didik pada masing-masing kategori kemampuan verbal. Uji komparasi rerata antar kolom dilakukan untuk mengetahui kategori kemampuan verbal mana yang lebih baik. Uji komparasi antar kolom ini menggunakan taraf signifikan 0,05 dengan metode Scheffe'. Berikut rangkuman hasil uji komparasi rerata antar kolom pada masing-masing kategori kemampuan verbal pada Tabel 5 .

Tabel 5. Rangkuman Hasil Uji komparasi Rerata Antar Kolom pada Masing-masing Kategori Kemampuan Verbal.

\begin{tabular}{ccccc}
\hline $\mathrm{H}_{0}$ & $\mathrm{~F}_{\text {hit }}$ & $\mathrm{F}_{\mathrm{a}}$ & Keputusan & Kesimpulan \\
\hline$\mu_{.1}=\mu .2$ & 28,57818645 & & Ditolak & $\mu .1 \neq \mu .2$ \\
$\mu .1=\mu .3$ & 94,81999398 & 6,14356 & Ditolak & $\mu .1 \neq \mu .3$ \\
$\mu .2=\mu .3$ & 231,3640353 & & Ditolak & $\mu .2 \neq \mu .3$ \\
\hline
\end{tabular}

Berdasarkan hasil uji komparasi rerata antar kolom pada masing-masing kategori kemampuan verbal maka diperoleh bahwa:

a. $\mathrm{H}_{0}$ pada $\mu .1=\mu_{\text {.2 }}$ yang berarti keputusan uji ditolak.

Hal ini menunjukkan bahwa terdapat perbedaan prestasi belajar matematika antara peserta didik yang memiliki kemampuan verbal tinggi dan peserta didik yang memilki kemampuan verbal sedang. Berdasarkan Tabel 5, rerata marginal prestasi belajar matematika peserta didik yang memiliki kemampuan verbal tinggi adalah 80 dan rerata marginal prestasi belajar matematika peserta didik yang memiliki kemampuan verbal sedang adalah 63,253. Dengan demikian, diperoleh kesimpulan bahwa prestasi belajar matematika peserta didik yang memiliki kemampuan verbal tinggi lebih baik dibandingkan prestasi belajar matematika peserta didik yang memiliki kemampuan verbal sedang.

b. $\mathrm{H}_{0}$ untuk $\mu_{.1}=\mu_{.3}$ yang berarti keputusan uji ditolak.

Hal ini menunjukkan bahwa terdapat perbedaan prestasi belajar matematika antara peserta didik yang memiliki kemampuan verbal tinggi dan peserta didik yang memilki kemampuan verbal rendah. Berdasarkan Tabel diatas, rerata marginal prestasi belajar matematika peserta didik yang memiliki kemampuan verbal tinggi adalah 80 dan rerata marginal prestasi belajar matematika peserta didik yang memiliki kemampuan verbal rendah adalah 41,1905. Dengan demikian, diperoleh kesimpulan bahwa prestasi belajar matematika peserta didik yang memiliki kemampuan verbal tinggi lebih baik dibandingkan prestasi belajar matematika peserta didik yang memiliki kemampuan verbal rendah.

c. $\mathrm{H}_{0}$ untuk $\mu .2=\mu .3$ yang berarti keputusan uji ditolak.

Hal ini menunjukkan bahwa terdapat perbedaan prestasi belajar matematika antara peserta didik yang memiliki kemampuan verbal sedang dan peserta didik yang memilki kemampuan verbal rendah. Berdasarkan Tabel 5, rerata marginal prestasi belajar matematika peserta didik yang memiliki kemampuan verbal sedang adalah 63,253 dan rerata marginal prestasi belajar matematika peserta didik yang memiliki kemampuan verbal rendah adalah 41,1905 . Dengan demikian, diperoleh kesimpulan bahwa prestasi belajar matematika peserta didik yang memiliki kemampuan verbal sedang lebih baik dibandingkan prestasi belajar matematika peserta didik yang memiliki kemampuan verbal rendah. 
3. $\mathrm{H}_{O A B}$ tidak ditolak. Berdasarkan Tabel 4, $\mathrm{H}_{0 A B}$ tidak ditolak menunjukkan bahwa tidak terdapat interaksi antara model pembelajaran dan kemampuan verbal terhadap prestasi belajar matematika. Dengan kata lain, prestasi belajar matematika peserta didik pada masing-masing kategori model pembelajaran konsisten terhadap masing-masing kategori kemampuan verbal atau prestasi belajar matematika peserta didik pada masing-masing kategori kemampuan verbal konsisten terhadap masing-masing kategori model pembelajaran. Sehingga tidak ada uji komparasi rerata antar sel pada masing-masing kategori model pembelajaran dan kemampuan verbal.

Pembahasan hasil penelitian berdasarkan pengujian hipotesis dan kajian pustaka adalah sebagai berikut.

\section{Hipotesis Pertama}

HoA: tidak terdapat perbedaan antara prestasi belajar matematika pada peserta didik yang dikenai model pembelajaran kooperatif tipe STAD modifikasi terbimbing dan model pembelajaran kooperatif tipe STAD

$\mathrm{H}_{1 \mathrm{~A}}$ : terdapat perbedaan antara prestasi belajar matematika pada peserta didik yang dikenai model pembelajaran kooperatif tipe STAD modifikasi terbimbing dan model pembelajaran kooperatif tipe STAD

Hasil analisis variansi dua jalan dengan sel tak sama pada uji hipotesis $\mathrm{H}_{0 \mathrm{~A}}$ (Tabel 4). Hasil keputusan uji adalah $\mathrm{H}_{0 \mathrm{~A}}$ tidak ditolak artinya bahwa tidak terdapat perbedaan prestasi belajar matematika pada peserta didik yang dikenai model pembelajaran kooperatif tipe STAD modifikasi terbimbing dan model pembelajaran kooperatif tipe STAD. Hasil penelitian ini tidak sesuai dengan hipotesis penelitian dan juga tidak sesuai dengan hasil penelitian yang relevan.

Beberapa hal yang menyebabkan hasil penelitian ini tidak sesuai dengan hipotesis penelitian dan penelitian relevan lainnya dapat disebabkan oleh beberapa kemungkinan. Kemungkinan pertama disebabkan pelaksanaan pembelajaran pada peserta didik yang dikenai model pembelajaran kooperatif tipe STAD modifikasi terbimbing kurang berjalan efektif yang disebabkan oleh waktu yang dibutuhkan dalam proses pembelajaran tidak sesuai dengan waktu yang sediakan. Selanjutnya, dalam proses pembelajaran tidak berjalan sesuai dengan rencana, tidak semua peserta didik mengikuti pembelajaran dengan baik. Dalam hal ini masih banyak dijumpai peserta didik yang lebih mengerti jika diajar dengan ceramah daripada penemuan terbimbing. Kendala-kendala ini sering dijumpai pada sekolah kelompok rendah. Kemungkinan kedua, peneliti belum pernah mengajar sehingga pelaksanaan proses pembelajaran tidak berjalan maksimal. Selain itu, tidak adanya pihak kedua yang dapat menilai peneliti dalam proses pembelajaran sehingga tidak ada timbal balik yang dapat membuat peneliti untuk dapat mengajar lebih baik lagi.

Dari kemungkinan tersebut, diduga yang menyebabkan penerapan model pembelajaraan kooperatif tipe STAD modifikasi terbimbing dan model pembelajaran kooperatif tipe STAD memiliki prestasi belajar yang sama baiknya. Dengan kata lain kedua model pembelajaran tersebut memberikan efek yang sama terhadap prestasi belajar matematika peserta didik. Walaupun demikian, peneliti percaya bahwa setiap peserta didik yang mengikuti proses pembelajaraan kooperatif tipe STAD modifikasi terbimbing dengan baik, maka prestasi belajar matematika peserta didik yang dikenai model pembelajaraan kooperatif tipe STAD modifikasi terbimbing tetap lebih baik daripada prestasi belajar matematika peserta didik yang dikenai pembelajaraan kooperatif tipe STAD. Hal ini akan nampak jelas pada jangka waktu dimasa yang akan datang, jika peserta didik tersebut sama-sama diuji ingatannya kembali. Dalam Rachmadi (2004: 7), kelebihan penemuan terbimbing 
adalah materi yang dipelajari dapat mencapai tingkat kemampuan yang tinggi dan lebih lama membekas karena peserta didik dilibatkan dalam proses penemuan. Hal ini karena model kooperatif tipe STAD modifikasi penemuan terbimbing, pada tahap kedua peserta didik diajak untuk dapat mengkonstruksi pengetahuan sendir dengan bantuan guru. Penemuan konsep yang peserta didik temukan akan lebih mudah diingat daripada peserta didik yang hanya mendapat informasi saja. Jadi disimpulkan bahwa perbedaan prestasi belajar peserta didik yang dikenai model pembelajaraan kooperatif tipe STAD modifikasi terbimbing dengan model pembelajaraan kooperatif tipe STAD terletak pada kemampuan peserta didik untuk dapat mengingat konsep-konsep matematika dalam waktu yang lama, dimana peserta didik yang dikenai model pembelajaraan kooperatif tipe STAD modifikasi terbimbing akan mudah mengingat konsep daripada peserta didik yang dikenai pembelajaraan kooperatif tipe STAD. Sesuai dengan Rachmadi (2004: 5), pengetahuan yang baru akan melekat lebih lama apabila peserta didik dilibatkan secara langsung dalam proses pemahaman dan mengkonstruksi sendiri konsep atau pengetahuan tersebut.

\section{Hipotesis Kedua}

$\mathrm{H}_{0 \mathrm{~B}}$ : tidak terdapat perbedaan prestasi belajar matematika pada peserta didik pada setiap kategori kemampuan verbal

$\mathrm{H}_{1 \mathrm{~B}}$ : terdapat perbedaan prestasi belajar matematika pada peserta didik pada setiap kategori kemampuan verbal

Hasil analisis variansi dua jalan dengan sel tak sama pada uji hipotesis $\mathrm{H}_{0 \mathrm{~B}}$ (Tabel 4). Hasil keputusan uji adalah $\mathrm{H}_{0 \mathrm{~B}}$ ditolak artinya bahwa terdapat perbedaan prestasi belajar matematika pada peserta didik pada setiap kategori kemampuan verbal. Sehingga terdapat uji komparasi antar kolom untuk meng etahui kategori kemampuan verbal mana yang lebih baik. Berdasarkan rangkuman Tabel 5 menyimpulkan bahwa prestasi belajar matematika peserta didik yang memiliki kemampuan verbal tinggi lebih baik daripada prestasi belajar matematika peserta didik yang memiliki kemampuan verbal sedang maupun rendah, dan prestasi belajar matematika peserta didik yang memiliki kemampuan verbal sedang lebih baik daripada prestasi belajar matematika peserta didik yang memiliki kemampuan verbal rendah. Hasil penelitian ini sesuai dengan hipotesis penelitian dan sesuai dengan hasil penelitian relevan.

Hasil penelitian secara umum menunjukkan bahwa prestasi belajar matematika peserta didik pada materi sistem persamaan linier dua variabel memiliki hubungan yang positif dengan kemampuan verbal. Semakin tinggi kemampuan verbal yang dimiliki peserta didik, semakin baik pula prestasi belajar matematika peserta didik pada materi sistem persamaan linier dua variabel.

\section{Hipotesis Ketiga}

$\mathrm{H}_{\mathrm{OAB}}$ : tidak terdapat perbedaan prestasi belajar matematika peserta didik yang memiliki kemampuan verbal tinggi, sedang dan rendah dikenai model pembelajaran kooperatif tipe STAD modifikasi penemuan terbimbing dengan peserta didik yang dikenai model pembelajaran kooperatif tipe STAD (tidak terdapat interaksi antara A dan B)

$\mathrm{H}_{1 \mathrm{AB}}$ : terdapat perbedaan prestasi belajar matematika peserta didik yang memiliki kemampuan verbal tinggi, sedang dan rendah dikenai model pembelajaran kooperatif tipe STAD modifikasi penemuan terbimbing dengan peserta didik yang dikenai model pembelajaran kooperatif tipe STAD (terdapat interaksi antara A dan B)

Berdasarkan Tabel 4, tidak terdapat interaksi antara model pembelajaran dengan kemampuan verbal. Hal ini konsisten dengan hubungan semakin tinggi kemampuan verbal maka prestasi belajar peserta didik semakin baik. Pada peserta didik yang memiliki kemampuan verbal tinggi, prestasi belajar matematika peserta didik yang dikenai model pembelajaran kooperatif tipe 
STAD modifikasi penemuan terbimbing sama baiknya dengan prestasi belajar matematika peserta didik yang dikenai model pembelajaran kooperatif tipe STAD. Hasil penelitian ini sesuai dengan hipotesis penelitian. Namun peneliti tidak menjamin bahwa peserta didik yang memiliki kemampuan verbal tinggi yang dikenai STAD modifikasi penemuan terbimbing dan STAD, memiliki prestasi belajar matematika yang sama jika peserta didik diuji kembali dalam jangka waktu yang lama. Hal ini dikarenakan peserta didik yang dikenai model pembelajaran kooperatif tipe STAD modifikasi penemuan terbimbing, hasil penguasaan konsep melekat lebih lama daripada peserta didik yang dikenai model pembelajaran kooperatif tipe STAD. Dalam Markaban (2006: 3), mengetahui adalah suatu proses, bukan suatu produk. Dalam Markaban (2006: 9), penemuan adalah suatu proses, suatu jalan/cara dalam mendekati permasalahan bukannya suatu produk atau item pengetahuan tertentu. Jadi pada saat peserta didik mengkonstruksi konsep sendiri dengan bimbingan guru maka proses mencari konsep tersebut akan mudah dingat oleh peserta didik karena peserta didik bukan hanya menerima informasi tapi juga melakukan. Rachmadi (2004: 5), pengetahuan yang baru akan melekat lebih lama apabila peserta didik dilibatkan secara langsung dalam proses pemahaman dan mengkonstruksi sendiri konsep atau pengetahuan tersebut.

Pada peserta didik yang memiliki kemampuan verbal sedang, prestasi belajar matematika peserta didik yang dikenai model pembelajaran kooperatif tipe STAD modifikasi penemuan terbimbing sama baiknya dengan prestasi belajar matematika peserta didik yang dikenai model pembelajaran kooperatif tipe STAD. Pada model pembelajaran kooperatif tipe STAD modifikasi penemuan terbimbing dan model pembelajaran kooperatif tipe STAD memberikan efek yang sama terhadap prestasi belajar matematika peserta didik sesuai dengan hipotesis pertama $\left(\mathrm{H}_{0 A}\right)$. Namun demikian, peserta didik yang dikenai model pembelajaran STAD modifikasi penemuan terbimbing tetap lebih baik daripada model pembelajaran kooperatif tipe STAD. Hal tersebut karena peserta didik yang diajar dengan penemuan terbimbing belajarnya lebih bermakna daripada peserta didik yang hanya menerima informasi. Sependapat dengan Trianto (2010: 7), berusaha sendiri untuk mencari pemecahan masalah serta pengetahuan yang disertainya, menghasilkan pengetahuan yang benar-benar bermakna.

Pada peserta didik yang memiliki kemampuan verbal rendah, prestasi belajar matematika peserta didik yang dikenai model pembelajaran kooperatif tipe STAD modifikasi penemuan terbimbing sama baiknya dengan prestasi belajar matematika peserta didik yang dikenai model pembelajaran kooperatif tipe STAD. Hasil penelitian ini megikuti hipotesis pertama $\left(\mathrm{H}_{0 \mathrm{~A}}\right)$ menyebutkan tidak terdapat perbedaan prestasi belajar matematika peserta didik yang dikenai model pembelajaran kooperatif tipe STAD modifikasi penemuan terbimbing dengan model pembelajaran kooperatif tipe STAD. Walaupun tujuan dari penerapan model pembelajaran kooperatif tipe STAD modifikasi penemuan terbimbing belum tercapai sesuai hipotesis penelitian, dalam membantu prestasi belajar peserta didik yang memiliki kemampuan verbal rendah untuk memiliki prestasi yang lebih baik daripada peserta didik yang dikenai model pembelajaran kooperatif tipe STAD. Namun peneliti percaya bahwa peserta didik yang memiliki kemampuan verbal rendah yang dikenai model pembelajaran kooperatif tipe STAD modifikasi penemuan terbimbing yang mengikuti proses pembelajaran dengan baik, maka prestasi belajar matematika mereka tetap tetap lebih baik daripada peserta didik yang dikenai model pembelajaran kooperatif tipe STAD. Peserta didik yang dikenai model pembelajaran kooperatif tipe STAD modifikasi penemuan terbimbing belajar lebih mandiri dari pada peserta didik yang dikenai model pembelajaran kooperatif tipe STAD. Penemuan terbimbing akan memberikan suatu pengalaman yang kongkret dan memberikan makna tersendiri bagi peserta didik. Dalam Trianto (2010: 7) mengungkapkan bahwa berusaha sendiri untuk mencari pemecahan 
Herlina, Eksperimentasimodel pembelajaran kooperatif tipe...

masalah serta pengetahuan yang disertainya menghasilkan pengetahuan yang benar-benar bermakna. Senada dengan Rachmadi (2004: 5), pengetahuan yang baru akan melekat lebih lama apabila peserta didik dilibatkan secara langsung dalam proses pemahaman dan mengkontruksi sendiri konsep atau pengetahuan tersebut. Penemuan terbimbing mengutamakan proses bukan hasil akhir. Sependapat dalam Markaban (2006: 3), mengungkapkan bahwa mengetahu adalah suatu proses, bukan suatu produk. Diperkuat juga oleh Marzano dalam Rachmadi (2004: 7), kelebihan penemuan terbimbing adalah materi yang dipelajari dapat mencapai tingkat kemampuan yang tinggi dan lebih lama membekas karena peserta didik dilibatkan dalam proses penemuan.

\section{KESIMPULAN}

Berdasarkan landasan teori, hasil penelitian yang mengacu pada hipotesis dan pembahasan, disimpulkan bahwa prestasi belajar matematika peserta didik SMA kelas X di Kota Surakarta pada materi sistem persamaan linier dua variabel adalah sebagai berikut:

1. Prestasi belajar matematika peserta didik yang dikenai model pembelajaran kooperatif tipe STAD modifikasi terbimbing sama baiknya dengan prestasi belajar matematika peserta didik yang dikenai model pembelajaran kooperatif tipe STAD.

2. Prestasi belajar matematika peserta didik yang memiliki kemampuan verbal tinggi lebih baik daripada prestasi belajar matematika peserta didik yang memiliki kemampuan verbal sedang maupun rendah, dan prestasi belajar matematika peserta didik yang memiliki kemampuan verbal sedang lebih baik dibandingkan prestasi belajar matematika peserta didik yang memiliki kemampuan verbal rendah.

3. Tidak terdapat interaksi antara model pembelajaran dengan kemampuan verbal. Dalam arti bahwa peserta didik yang memiliki kemampuan verbal tinggi, prestasi belajar matematika peserta didik yang dikenai model pembelajaran kooperatif tipe STAD modifikasi penemuan terbimbing sama baiknya dengan prestasi belajar matematika peserta didik yang dikenai model pembelajaran kooperatif tipe STAD; peserta didik yang memiliki kemampuan verbal sedang, prestasi belajar matematika peserta didik yang dikenai model pembelajaran kooperatif tipe STAD modifikasi penemuan terbimbing sama baiknya dengan prestasi belajar matematika peserta didik yang dikenai model pembelajaran kooperatif tipe STAD; peserta didik yang memiliki kemampuan verbal rendah, prestasi belajar matematika peserta didik yang dikenai model pembelajaran kooperatif tipe STAD modifikasi penemuan terbimbing sama baiknya dengan prestasi belajar matematika peserta didik yang dikenai model pembelajaran kooperatif tipe STAD.

\section{SARAN}

Berdasarkan pembahasan dan kesimpulan diatas, dikemukakan beberapa saran untuk peneliti sebagai berikut:

1. Dalam penelitian ini, prestasi belajar matematika pada peserta didik yang dikenai model pembelajaran kooperatif tipe STAD dan model pembelajaran kooperatif tipe STAD modifikasi terbimbing memiliki prestasi yang sama baiknya atau kedua model pembelajaran memiliki efek yang sama terhadap prestasi belajar matematika. Hasil penelitian ini tidak sesuai dengan hipotesis penelitian, disebabkan oleh beberapa faktor yang sudah dibahas dalam uraian diatas. Sehingga peneliti lain hendaklah memperhatikan kemungkinan-kemungkinan yang menyebabkan hasil penelitian ini tidak sesuai dengan hipotesis penelitian. 
2. Hendaknya peneliti lain dapat menerapkan kembali model pembelajaran kooperatif tipe STAD modifikasi terbimbing dengan model pembelajaran kooperatif tipe STAD pada materi lain dan tinjauan lain sehingga dapat mengembangkan proses pembelajaran yang lebih bermakna.

\section{REFERENSI}

Balfakih, Nagib. (2003). The effectiveness of student team-achievement division for teaching high school chemistry in the united arab emirates. International journal of science education, 25(5), 605-624.

Budiyono. (2003). Metodologi penelitian pendidikan. Surakarta: Sebelas Maret University

Budiyono. (2009). Statistik untuk penelitian (edisi kedua). Surakarta: Sebelas Maret University Press.

Jujun S Suriasumatri. (2007). Filsafat ilmu: Sebuah pengantar populer. Jakarta: Pustaka Sinar Harapan.

M. Hariwijaya. (2005). Tes Inteligensi. Yogyakarta: Andi Offset.

Markaban. (2006). Model pembelajaran matematika dengan pendekatan penemuan terbimbing. Yogyakarta.

Mumba. (2007). Analysis of new zambian high school shysics syllabus and practical examinations for levels of inquiry and inquiry skills. Eurasia Journal of Mathematics, Science \& Technology Education, 3(3), 213-220.

Sugianto. (2010). Model-model pembelajaran inovatif. Surakarta: Yuma Pustaka bekerja sama dengan FKIP UNS.

Trianto. (2010). Mendesain model pembelajaran inovatif-progresif. Jakarta: Prenada Media. 